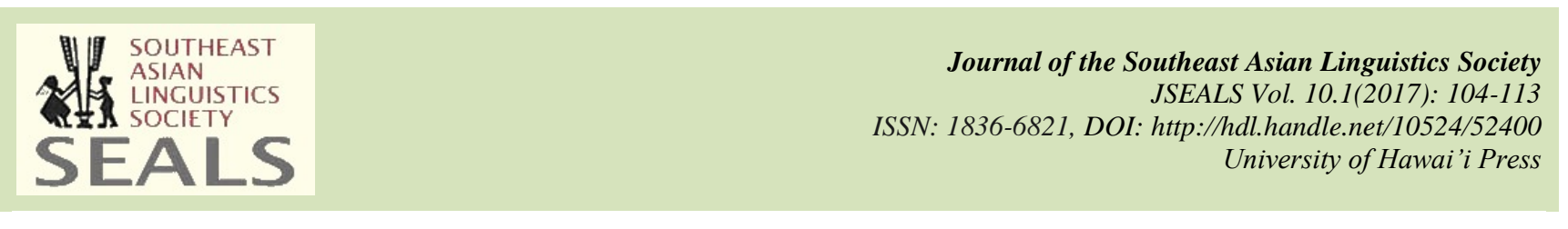

\title{
DISCOURSE FUNCTIONS OF ZERO PRONOUNS IN TAI DAM ${ }^{1}$
}

\author{
Itsarate Dolphen \\ Research Institute for Languages and Cultures of Asia, Mahidol University, \\ Salaya, Nakon Pathom 73170, Thailand \\ itsdol@kku.ac.th
}

\begin{abstract}
The aim of this study is to explore zero pronouns in Tai Dam through a discourse approach using Systemic Functional Grammar (SFG). The objectives of this paper are as follows: (1) to explore the syntactic distribution of zero pronouns in Tai Dam, and (2) to analyze the discourse functions of zero pronouns in Tai Dam narratives. The research data used in this paper were collected from the texts of Tai Dam folktales of Tai Dam living in Petchaburi Province in central Thailand. Five folktales were analyzed for the study. The main findings include the following: (a) Zero pronouns can occur in both Theme and Rheme positions; (b) In thematic positions, they function as unmarked topical themes; (c) As for discourse functions of zero pronouns in terms of co-references, the two types of co-reference of zero pronouns in Tai Dam include zero anaphora and zero cataphora; (d) The main discourse functions of zero pronouns are to signal an active referent in narrative discourse and to highlight a participant.
\end{abstract}

Keywords: Discourse functions, zero pronouns, Tai Dam, narrative discourse ISO 639-3 codes: blt

\section{Introduction}

The Tai Dam (Black Tai) belongs to the Tai-Kadai language family (Burusphat 1981). Originally, the Tai Dam speaking people settled in Dien Bien Phu in Vietnam, and then some of them moved to Laos and Thailand. Tai Dam speakers currently reside in some lower parts of China such as Guangxi and Yunnan, as well as in the Tonkin of North Vietnam. In 1895 of the Thonburi period, they migrated to Thailand because of the disaster of war. In Thailand, Tai Dam can be found in many provinces such as Lei, Saraburi, Supanburi, Ratchaburi, Petchaburi, Nakon Pathon, and so on. The Tai Dam language has its own alphabet. We can study Tai Dam language and culture through documents written either in the Tai Dam alphabet or transcribed into others, such as Vietnamese. These narratives and other written resources of the Tai Dam people can be used as research data to study aspects of Tai Dam discourse.

Tai Dam is considered a pro-drop language in which certain clauses or pronouns may be omitted when they are pragmatically inferable. The phenomenon of 'pronoun-dropping' is also commonly referred to in linguistics as zero or null pronouns. A zero pronoun has a function but is not uttered. It is a subsequent null reference that refers to an argument in preceding text. A zero pronoun in this study also includes the zero form in serial verb constructions. In some languages, zero pronouns can appear either in the subject or the object grammatical position, such as in Japanese, Chinese and Thai. However, some languages might be considered partial pronoun-drop languages in that they allow only the subject pronoun to be dropped. In Spanish texts, zero pronouns only appear in the position of the subject, and so it is considered a null subject language. In a non-pro-drop language such as English, zero pronouns can also occur, but they appear less frequently since they are used in coordinated sentences in which the zero pronouns usually refer to the subject of the clause. According to Edwards (2011: 69), in the Tai Dam texts, zero anaphora functions to signal an accessible referent that is unambiguous. Those referents can be in the subject or object position.

At the discourse level, the structure of Theme can show how full pronouns are selected as marked or unmarked. The problem is whether zero pronouns are selected as marked or unmarked under Theme structure and whether they share the same functions with their full form. This paper argues that by tracking

1 This paper is part of $\mathrm{PhD}$ thesis entitled 'A Comparison Study of Pronouns in Narrative Discourse in Southeast Asian Languages'. 
an active participant via its proform and pro-drop form, we can explain discourse functions of full pronouns and zero pronouns in narrative discourse. The aim of this study is to explore the so-called 'zero pronouns' in Tai Dam on the basis of the discourse approach of the Systemic Functional Grammar (SFG). The main goals as follows: (1) to analyze the syntactic distributions of zero pronouns in narrative discourse of the Tai Dam, and (2) to explore the discourse functions of zero pronouns in the Tai Dam.

This paper is divided into five sections. The first section is an introduction which briefly lays out the background of the study. The second section presents the research data used in this paper. The third section displays the notions of theoretical frame work and associated research. The results of the study are discussed in the fourth section. Lastly, the fifth section concludes the paper and provides recommendations for further study.

\section{Data for the study}

The data on which the analysis was based were collected from secondary sources. There are five folktales from a collection by Udomwej (1985) used in this study, namely, (1) Red Duck, (2) A Story of a Tiger, (3) Mister Nga and Mister Daeng, (4) A Story of Dogs and Cats, and (5) A Story of Deaf People. In order to detect zero pronouns within thematic structure, texts should be divided into clauses. After that, each clause will be considered under Theme-Rheme structure since different types of clauses, such as declarative, interrogative, imperative are considered in different typical thematic structures in which elements will be picked up as a Theme. The data is translated word by word and then presented in free translation. Only pronouns which are omitted in the texts are taken to analyze. Zero pronouns in a conversation quoted by narrators are not chosen in this study.

\section{SFG and the study of zero pronouns}

\subsection{Relevant Concepts in SFG}

In this section, SFG will briefly be described in terms of its application to discourse analysis. SFG textual metafunction is mainly applied in this study in particular modes of meanings.

SFG currently holds a prominent place in linguistic theory and has been continuously developed over fifty years, originally by Halliday (1956) and then by many other linguists: Hasan (1978); Martin (1992); Butt et al. (2000); Thompson (2004); Halliday and Matthiessen (2004). SFG is a model of grammar. The term 'systemic' refers to the view of language as a network of systems, or interrelated sets of choices for creating meaning. The term 'functional' means the approach is concerned with the contextualized and practical uses to which language is put.

According to SFG, language is viewed as a kind of complex, adaptive system or a network of systems. It is also interpreted as being potential diversified functionally into three simultaneous modes of meaning (Halliday and Matthiessen 1999) that are known as metafunctions. Of these metafunctions, (1) ideational metafunction (logical and experiential), (2) interpersonal metafunction, and (3) textual metafunction, all of which SFG deals within the grammatical system itself, only the textual metafunction is selected as the main focus of this study. The reason is that the textual metafunction creates discourse. It helps to organize the message within and between clauses, and is closely related to the narrative's cohesion and coherence. The phenomenon of cohesion can be linked to this metafunction. As point of fact, pronouns in general can be studied as grammatical devices that are central to a narrative text's cohesion. The textual metafunction focuses on the notion of how we organize our messages in ways that indicate how they fit in with the other messages around them and within the wider context in which we are talking or writing (cf. Thompson 2004).

The textual metafunction utilizes Theme and Rheme for exploring how meanings are created and understood. By focusing on pronouns, the textual meaning, or as topical Theme, a zero pronoun needs to recover its original meaning from context. According to Patpong (2002:180), a Theme will provide local context for information, whereas a Rheme will elaborate information. This characteristic can also be applied to textual organization of narrative discourse and the flow of pronouns in which Theme is realized by initial position in the clause as the 'point of departure' and Non-Theme or Rheme is realized by the remainder of the clause. Pronouns can be retrieved from both Theme and Rheme. That is why the textual metafunction matches the purpose of the study. 


\subsection{The study of pronouns}

Pronouns are a functional word which plays a crucial part in all languages. Pronouns, both full and zero, have been studied worldwide: Spanish: Luis and D' Introno 2001; Thai: Aroonmanakun 2000; Chinese: Zhao and Ng 2007; Japanese: Kawahara and Kurohashi 2004; Korean: Roh and Lee 2006; Lao: Compton 1992; Turkish: Gürel 2002, to name a few. Both full pronouns (overt) and zero pronouns (covert) have been researched theoretically and differently in many language families.

Pronouns can simply be treated as a proform which is a type of functional word substituting for a noun or a noun phrase where the meaning is recoverable from the context. It can be said that they are used to avoid repetitive elements. Pronouns can be presented in different forms, with or without a determiner, depending upon the context and the nature of the language itself. Synchronically, pronouns have been studied in the area of their usage concerned with social factors and situational contexts of grammar, such as in Pronouns and People: the Linguistic Construction of social and Personal Identity (Muhlhausler and Harre 1990). This research is based on a broad corpus of data from many diverse cultures.

In Tai languages, pronouns have been explored diachronically and synchronically. Strecker (1984) has studied Proto-Tai personal pronouns. Hartmann (1992) has researched Diachrony and Sociological Shifts in Tai Pronouns Historically. In Thai, Palakornkul (1985) produced A Socio-Linguistic Study of Pronominal Strategy in Spoken Bangkok Thai. That study describes pronominal usage in spoken Bangkok Thai from a socio-linguistics point of view. Research on pronouns in Thai was conducted by Chomaitong (1974) in A Contrastive Analysis of English and Thai Pronouns. Bamroongraks (1987) wrote a dissertation entitled Sukhothai Thai as a discourse-oriented language: Evidence from zero noun phrases based on inscriptions. Sukonthaman'1989 dissertation was on A Comparison of Thai Second Person Pronominal Acquisition by Central Thai and Lahu Children (Pronominal Acquisition). Indrambarya (2010) wrote an article on Zeropronoun subjects in Thai. She found that zero-pronoun subjects are used both within sentences and between sentences. The zero-pronoun subject can occur before or after its referents. It was also found that the thirdperson pronouns are referred to often in online newspapers.

However, none of the works mentioned clarify the characteristics of zero pronouns in terms of discourse functions. This paper elaborates on these particular functions when they are dealt with narrative discourse.

Some other works have explored pronouns in discourse in Thai and Southeast Asian languages. Pronouns can be analyzed as participant references, in particular covert and overt instances such as in IuMienh narrative discourse studied by Maneekhao (1990). The study found that the conditions on usage of participant references can be divided into two types: linguistic conditions and participant conditions. In addition, the result of the analysis shows that the choice of reference depends on characteristics of each reference and the conditions posed in each case.

Aroonmanakun (1997, 1999, and 2000) has studied zero pronouns in the Thai language based on centering theory. This theory posits a focusing process in which salience of discourse entities is kept track of. However, he states that the centering model can resolve only pronouns or zero pronouns whose antecedents are in the immediately preceding utterance. He indicates that antecedents of Thai zero pronouns are not always in the immediately preceding utterance. Discourse structure is hypothesized as relevant for resolving zero pronouns, and the centering model was extended to work within the hierarchical structure of discourse. In the end, it was found that the extended model did not perform better than existing models because most of the pronoun antecedents are in the immediately preceding utterance. A few are in distant utterances. Coreferences of these zero pronouns could be explained in terms of hierarchical structure of clauses, which seems to operate at the sentence level rather than at the discourse level. Thus, in Aroonmanakun's work, centering model cannot explain zero pronouns at discourse level, especially when text discontinuity occurs. A referential chain of zero pronouns under Theme-Rheme structure will help to clarify zero pronouns in a distant utterance.

At the present time, discourse functions of zero pronouns of Tai Dam have not been explored in discourse studies. This study attempts a rigorous analysis of zero pronouns in this particular language and the findings of this study may give insight into all the Tai languages, including Standard Thai.

\section{The results}

It has been found that zero pronouns in narrative discourse of Tai Dam can occur in both Theme and Rheme positions. In Theme position, zero pronouns can be the unmarked topical theme functioning as a subject of a clause. In Rheme position, zero pronouns can function as the object of a clause. In this section, the syntactic 
distribution of zero pronouns in narrative discourse will be discussed first and then the discourse functions of zero pronouns will be illustrated later.

A zero pronoun has a function but does not have form in language use. It is a subsequent null reference that refers to preceding text. In order to detect zero pronouns within thematic structure, texts must be divided into clauses. After that, each clause is considered under Theme-Rheme structure since different types of clauses, such as declarative, interrogative, imperative are considered in different typical thematic structures where elements will be picked up as Theme. As zero pronouns stand in for nouns, a noun group or a full pronoun but not realized in speech, wherever those nouns or pronouns can appear in clauses, the zero pronouns themselves can accomplish the same semantico-syntactic effect.

Example 1 shows the position of zero pronouns standing in for a noun or a pronoun (e.g. man 'he/she/it') in Theme structure functioning as the subject of a clause.

Example 1: Zero pronouns standing in for a noun functioning as the subject of a clause

\begin{tabular}{|c|c|c|c|c|}
\hline \multirow[t]{2}{*}{ No. } & \multicolumn{3}{|c|}{ Theme } & \multirow[t]{2}{*}{ Rheme } \\
\hline & Text. & $\begin{array}{c}\text { Topical } \\
\text { (unmarked) }\end{array}$ & Text. & \\
\hline CL2.1 & $\begin{array}{l}\text { thi: } n i: \\
\text { now_then }\end{array}$ & $\begin{array}{l}\text { la:n ca:j } \\
\text { nephew }\end{array}$ & & $\begin{array}{l}\text { pen khon cho:p thiaw } \\
\text { to_be person like travel }\end{array}$ \\
\hline CL2.2 & & $\begin{array}{l}(0: \text { man }) \\
\sqrt{3 s g}\end{array}$ & & $\begin{array}{llll}\text { pen khon } & \text { chっ:p } & \text { thiaw } \\
\text { to_be } & \text { person } & \text { like } & \text { travel }\end{array}$ \\
\hline CL2.3 & & ( & & $\begin{array}{lll}\text { paj } & \text { thiaw pa: } & \text { chin lr:j } \\
\text { go travel forest } & \text { PRT }\end{array}$ \\
\hline CL2.4 & & $\begin{array}{l}\text { (O: man) } \\
\text { 3sg }\end{array}$ & & $\begin{array}{ll}\text { thiaw pa: } & \text { loe: } w \\
\text { travel forest } & \text { MOD }\end{array}$ \\
\hline
\end{tabular}

'The nephew loved traveling. (He) loved traveling. (He) went and traveled at the jungle. (He) traveled in the jungle.'

Zero pronouns are quite different from full pronouns in terms of the position of zero pronouns in Theme position. It has been found that zero pronouns in Tai Dam can be realized in unmarked theme. A Tai Dam speaker can assume that the listener already knows about or can be access what is already mentioned. We can say that a native speaker can place zero pronouns in a clause grammatically. The symbol (.......) in Table 1 stands for a position where a full pronoun is supposed to be placed grammatically by a native speaker. The symbol $\varnothing$ : man in parentheses refers to a zero pronoun of the full pronoun man. Zero pronouns function as subject of the clause just the same as the full pronouns do.

As we can see in Example 1, the zero pronoun of the full pronoun man 'he' can be realized under unmarked topical theme in CL2.2. The zero pronoun in this example functions as subject of the clause as its original full form does in CL2.1. For the next two clauses, it was found that the zero pronoun is still selected to maintain the referential chain. In CL2.3 and CL2.4, the zero pronouns are realized as unmarked topical themes functioning as subjects of clauses as well.

As mentioned before, nouns or pronouns can function as objects of clauses. As a zero pronoun, it can function as objects of clauses as well. Example 2 shows how a zero pronoun functions as an object under Rheme position.

Example 2: A zero pronoun functioning as an object under Rheme position

\begin{tabular}{|c|c|c|c|c|}
\hline \multirow{2}{*}{ No. } & \multicolumn{3}{|c|}{ Theme } & \multirow{2}{*}{ Rheme } \\
\hline & Text. & $\begin{array}{l}\text { Topical } \\
\text { (unmarked) }\end{array}$ & Text. & \\
\hline CL43.1 & & man & $\begin{array}{l}\text { ko? } \\
\text { then }\end{array}$ & 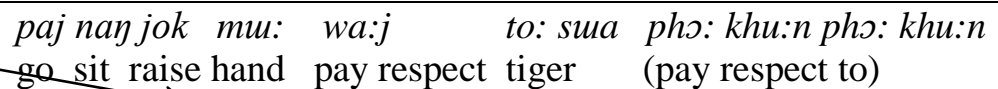 \\
\hline CL43.2 & & $\begin{array}{l}\text { to: swa } \\
\text { tiger }\end{array}$ & & $\begin{array}{l}\text { top hu: }(\varnothing: \text { man) kha:t paj sa? hu: nuk } \\
\text { snatch ears } \quad \text { 3sg tear } \quad \text { DIV PRT ear one }\end{array}$ \\
\hline
\end{tabular}

'He then sat down and paid respect to the tiger. The tiger snatched one of his ears off.' 
Example 2 is retrieved from the story Red Duck. As we can see, the zero pronoun of the full pronoun man 'he' is part of the possessive construction hu:man 'his ears', but the possessive marker khosy is dropped. The zero pronoun in this example is realized under Rheme position. The word hu: 'ears' is considered to be the object of the clause, and the pronoun man 'he' is a modifier of a noun.

There are several benefits of using SFG to analyze the syntactic functions of pronouns. SFG is valuable in differentiating subjects and objects in clauses. In examining surface structure, the concept of ThemeRheme structure is useful in specifying subjects and objects in clauses. As every single clause is segmented to analyze pronouns within a Theme-Rheme distribution, a pronoun which is a Theme is more likely to be associated with a subject, not an object The sentence structure SVO cannot specify that the pronoun occurring before a verb is the subject of a clause or that the one followed by a verb is an object. This analysis is applicable to languages where word forms are not changed into signal functions and parts of speech. In cases where an overt indefinite/definite noun group is considered to be a double subject construction, a pronoun which is adjacent to its Topic (descriptive) will indicate that this particular topic functions as the subject of a clause, including itself and is a point of departure for a clause. As for zero pronouns, which are not realized in speech but are contextually interpreted by native speakers, under Theme position, zero pronouns can play a role just as full pronouns do. In a possessive construction and an interrogative construction, zero pronouns cannot be selected.

The following topics will be discussed regarding the syntactic distribution and discourse functions of zero pronouns in narrative discourse of Tai Dam. The syntactic distribution of zero pronouns will be illustrated first, and then the discourse functions of zero pronouns will be discussed.

\subsection{The syntactic distribution of zero pronouns in narrative discourse of Tai Dam}

It was found that a zero pronoun in Tai Dam can appear right after its antecedent referent in two main patterns. If we look at the ordering of zero pronouns in discourse within one referential chain, it can be seen that a zero pronoun can appear adjacent to its full pronoun mentioned in a preceding clause. Zero pronouns can appear adjacent to their referents introduced in preceding clauses. Both patterns can be shown as follows.

\section{The referent + full pronouns + zero pronouns}

In Example 3 taken from a Story of Deaf People, we find that the zero pronoun of the full pronoun man 'he' realized as an unmarked Theme can point back to its referent introduced in CL16.1. But in the sentences, it is interrupted by the full pronoun man in CL16.2.

Example 3: The syntactic distribution of zero pronouns in narrative discourse (Pattern I)

\begin{tabular}{|c|c|c|c|}
\hline \multirow[t]{2}{*}{ No. } & \multicolumn{2}{|l|}{ Theme } & \multirow[t]{2}{*}{ Rheme } \\
\hline & $\begin{array}{c}\text { Topical } \\
\text { (unmarked) }\end{array}$ & Text. & \\
\hline CL16.1 & $\begin{array}{l}\text { lu? khwaj thaw } \\
\text { son-In-taw }\end{array}$ & $\begin{array}{l}\text { thi: } \\
\text { who }\end{array}$ & $\begin{array}{l}\text { wa: mша ki: ni: } \\
\text { say just now }\end{array}$ \\
\hline CL16.2 & $\begin{array}{l}\text { man } \\
\text { 3sg }\end{array}$ & & $\begin{array}{ll}\text { hu: } n u a ? & \text { ju: } \\
\text { deaf } & \text { FP }\end{array}$ \\
\hline \multicolumn{4}{|c|}{ ‘The son-in-law who just was mentioned was deaf.’ } \\
\hline CL17.1 & $\begin{array}{l}(\varnothing: \text { man }) \\
\downarrow 3 \text { sg }\end{array}$ & & $\begin{array}{llll}f a \eta & \text { ma? } & \text { hu: } & \text { hway } \\
\text { listen } & \text { NEG } & \text { know } & \text { story } \\
\end{array}$ \\
\hline CL17.2 & $\begin{array}{l}\text { (Ø:man) } \\
\text { 3sg }\end{array}$ & & $\begin{array}{lllll}f a \eta & \text { ma? } & \text { hu: } & \text { hway } & \text { kan } \\
\text { listen } & \text { NEG } & \text { know story } & \text { FP }\end{array}$ \\
\hline
\end{tabular}

'(He) didn’t understand. (He) didn’t understand.'

Concerning the ordering of zero pronouns and their referents introduced elsewhere in discourse, the following is another pattern of a zero pronoun occurring in a clause.

\section{The referent + zero pronouns}

Zero pronouns can appear adjacent to their referents which are introduced in the proceeding clause as in Example 4. 
Example 4: The syntactic distribution of zero pronouns in narrative discourse (Pattern II)

\begin{tabular}{|c|c|c|c|c|}
\hline \multirow[t]{2}{*}{ No. } & \multicolumn{3}{|c|}{ Theme } & \multirow[t]{2}{*}{ Rheme } \\
\hline & Text. & $\begin{array}{c}\text { Topical } \\
\text { (unmarked) }\end{array}$ & Text. & \\
\hline CL22.1 & & $\frac{n u:}{\sqrt{\text { rat }}}$ & & $\begin{array}{llll}\text { thre? thay khwan } & \text { lr:j } & n r: j \\
\text { gnaw all night } & \text { FP } & \text { FP } \\
\end{array}$ \\
\hline CL22.2 & & $\begin{array}{l}\text { (Ø: man) } \\
\text { 3sg }\end{array}$ & & $\begin{array}{l}\text { thre kam pan kJ: hi:n ma:j nan } \\
\text { gnaw boat then see wood that }\end{array}$ \\
\hline \multicolumn{5}{|c|}{ 'The rat gnawed all night. (It) gnawed a boat and then (it) saw that wood.' } \\
\hline CL23.1 & $\begin{array}{l}\text { lae: } w \\
\text { then }\end{array}$ & $\begin{array}{l}(\varnothing: \text { man }) \\
\text { 3sg }\end{array}$ & & $\begin{array}{l}\text { pho: khaw } \\
\text { rush DIV }\end{array}$ \\
\hline CL23.2 & & $\begin{array}{l}\text { (Ø: man) } \\
\text { 3sg }\end{array}$ & & $\begin{array}{lll}\text { ?aw } & \text { ke: } w & \text { Po? ma: laj } \\
\text { take } & \text { precious stone out DIV can }\end{array}$ \\
\hline
\end{tabular}

'Then (it) rushed. (It) could take a precious stone out.'

\begin{tabular}{l|c|c|c|c}
\hline CL24 & $\begin{array}{c}\text { thi: } n i: \\
\text { now_then }\end{array}$ & $\begin{array}{c}\text { ma: } w \\
\text { cat }\end{array}$ & $\begin{array}{c}\text { ks: } \\
\text { then }\end{array}$ & $\begin{array}{l}\text { Paw loy ma: } \\
\text { take DIV DIV }\end{array}$ \\
\hline
\end{tabular}

'At this time, the cat took (the precious stone from the cat).'

Example 4 is taken from a Story of Dogs and Cats. It shows that the zero pronoun of the full pronoun man 'it' can be supplied grammatically in the clause CL22.2, CL23.1 and CL23.2. These zero pronouns refer to the referent in CL22.1. As we can see, the zero pronoun man ends its referential chain when a new referent is introduced. As a new participant, me: $w$ 'cat' is introduced, and the zero pronoun of the full pronoun man is ended.

If we look at a pronoun that is one kind of proform, we can distinguish between anaphora and cataphora. Like full pronouns, zero pronouns stand in for nouns and full pronouns. One can distinguish between anaphora of zero pronouns as well as a cataphora of pronouns. Because of this, both full pronouns and zero pronouns refer to the same referent. When two or more expressions refer to the same referent in discourse, linguistically they are co-referent; the one is a full form (the antecedent), and the other is an abbreviated form (a pronoun or anaphor) or even a zero form. It was found that there are two types of co-reference of zero pronouns in Tai Dam data as follows.

\subsubsection{Zero anaphora of pronouns}

A zero anaphora refers to anaphoric reference in which a zero form of a pronoun follows its antecedent introduced elsewhere in the discourse. This kind of reference is used to create a chain of references in developing narrative discourse, as in Example 5.

Example 5: Zero anaphora creating a chain of references in developing narrative discourse

\begin{tabular}{|c|c|c|c|}
\hline \multirow[t]{2}{*}{ No. } & \multicolumn{2}{|c|}{ Theme } & \multirow[t]{2}{*}{ Rheme } \\
\hline & $\begin{array}{c}\text { Topical } \\
\text { (unmarked) }\end{array}$ & Text. & \\
\hline CL113.1 & phwan & $\begin{array}{l}l r: j \\
\text { then }\end{array}$ & $\begin{array}{l}\text { Paw }(\varnothing: \text { man }) \text { ma: } \text { ?et } \\
\text { take } \quad \text { 3sg DIV make }\end{array}$ \\
\hline CL113.2 & (Ø: phman) & & 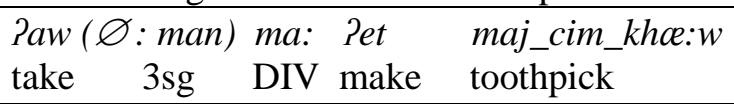 \\
\hline CL113.3 & $\begin{array}{l}\text { (Ø: phwan) } \\
\text { 3sg }\end{array}$ & & $\begin{aligned}(\varnothing: \text { ?aw man) ma: Pet } & \text { maj_cim_khoe:w } \\
\text { take 3sg DIV make } & \text { toothpick }\end{aligned}$ \\
\hline
\end{tabular}

'He then took (it) to make a toothpick. (He) took (it) to make a toothpick. (He took it) to make the toothpick.' 
In Example 5, the zero pronoun of the full pronoun phwan 'he' in CL113.2 and CL113.3 displays the full forms of the pronoun. This full pronoun here acts as the antecedent referent of its zero pronoun. The primary antecedent referent is introduced elsewhere in the preceding text.

\subsubsection{Zero cataphora of pronouns}

A zero cataphora refers to cataphoric reference in which a zero form of a pronoun precedes its postcedent that is not yet introduced. This kind of reference is used for introducing a protagonist to be introduced into discourse as in Example 6.

Example 6: Zero cataphora introducing a protagonist to be introduced into discourse

\begin{tabular}{c|c|c|ll}
\hline \multirow{2}{*}{ No. } & \multicolumn{2}{|c|}{ Theme } & \multicolumn{2}{c}{ Rheme } \\
\cline { 2 - 3 } & Text. & $\begin{array}{c}\text { Topical } \\
\text { (unmarked) }\end{array}$ & \\
\hline CL23 & $\begin{array}{c}\text { loe: } w \\
\text { then }\end{array}$ & $\begin{array}{c}\text { Ø: man) } \\
\text { 3sg }\end{array}$ & $\begin{array}{l}\text { ta:j ha: bu? ka:p ni: } \\
\text { die PRT time this }\end{array}$ \\
\hline
\end{tabular}

Then, (he) might be deark now.

\begin{tabular}{|c|c|c|}
\hline CL24 & $\begin{array}{l}\text { Paj da: } y \\
\text { HON Daeng }\end{array}$ & $\begin{array}{l}\text { cap pa: paj met loe: } w \\
\text { catch fish DIV all already }\end{array}$ \\
\hline
\end{tabular}

Example 6 shows that the zero pronoun man 'he' precedes the expression to which it refers. This is its postcedent Paj doe: $\eta$ 'Mister Daeng'. The postcedent referent is considered to be an unmarked topical theme functioning as the subject of the clause in CL24. The zero cataphoric referent of the full pronoun man 'he' and the full form ?aj do: $\eta$ 'Mister Daeng' refers to the same item. Therefore, they are coreferential.

\subsection{Discourse functions of zero pronouns in narrative discourse of Tai Dam}

A zero pronoun performs different functions in discourse. It can function either as a subject or an object of a clause in general within a Theme and Rheme structure. In narrative discourse, when a participant is first introduced in a text, he or she might be referred to as the antecedent referent. The abbreviated form recognized as a pronoun will be replaced in the subsequent clauses. However, if that particular participant is still active, zero anaphora will be used as a strategy to avoid repetition of pronoun and to signal an active referent. The active referent refers to a referent that was introduced in a story and has as activation status. As the story moves on other topics, if the referent is mentioned again, it becomes active again. Example 7 shows how a zero pronoun in Tai Dam is used to signal an active referent as in Example 7.

Example 7: A zero pronoun used to signal an active referent in discourse (I)

\begin{tabular}{c|c|c|c|l|l}
\hline \multirow{2}{*}{ No. } & \multicolumn{3}{|c|}{ Theme } & & Rheme \\
\cline { 2 - 4 } & Text. & $\begin{array}{c}\text { Topical } \\
\text { (unmarked) }\end{array}$ & Text. & \\
\hline CL6 & $\begin{array}{c}\text { thi: } n i: \\
\text { now_then }\end{array}$ & $\begin{array}{c}\text { man } \\
\text { 3sg }\end{array}$ & $\begin{array}{c}\text { kos? } \\
\text { then }\end{array}$ & $\begin{array}{l}\text { paj } \\
\text { go }\end{array}$ \\
\hline
\end{tabular}

'Now, he went (traveling) $\%$.

\begin{tabular}{|c|c|c|}
\hline CL7.1 & $\begin{array}{l}(\varnothing: \text { man }) \\
\downarrow 3 \text { sg }\end{array}$ & $\begin{array}{l}\text { paj t6r: law } \\
\text { go find } \text { PRT }\end{array}$ \\
\hline CL7.2 & $\emptyset^{(\varnothing ; m a n)}$ & $\begin{array}{l}\text { paj po: to: pet } \\
\text { go find CLF duck } \\
\text { khaw to: nuy pet doe: } \\
\text { DV } \text { CLF NUM duck red }\end{array}$ \\
\hline CL7.3 & $\begin{array}{l}\text { (Ø: man) } \\
\text { 3sg }\end{array}$ & 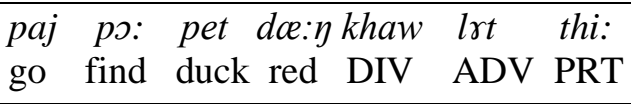 \\
\hline
\end{tabular}

'(He) went to find. (He) went to find a duck, the red duck. (He) went to find the red duck.' 
Example 7 shows that the pronoun in Tai Dam man 'it' is omitted in many clauses from CL7.1 to CL7.3 within an unmarked topical theme functioning as a subject in clauses. Only the first clause shows a full pronoun man 'it', which is explicit; the other clauses show the implicit quality of pronouns in order to avoid repetition. This zero pronoun is referred back to its referents to signal that the participant is still active. The using of zero anaphoric reference makes a clause smoother and makes it easier to enunciate as well.

One more example of zero pronouns functioning as a cohesive device to signal an active referent is retrieved from a Story of a Tiger as in Example 8.

Example 8: A zero pronoun used to signal an active referent in discourse (II)

\begin{tabular}{|c|c|c|c|c|}
\hline \multirow[t]{2}{*}{ No. } & \multicolumn{3}{|c|}{ Theme } & \multirow[t]{2}{*}{ Rheme } \\
\hline & Text. & $\begin{array}{c}\text { Topical } \\
\text { (unmarked) }\end{array}$ & Text. & \\
\hline CL2.1 & $\begin{array}{l}\text { thi: } n i: \\
\text { now_then }\end{array}$ & $\begin{array}{l}\text { Paj kon haw } \\
\text { HON person }\end{array}$ & $\begin{array}{l}\text { thi: } \\
\text { who }\end{array}$ & $\begin{array}{l}\text { paj pa: ni: } \\
\text { go jungle this }\end{array}$ \\
\hline CL2.2 & & $\begin{array}{c}\text { kon } \\
\text { pepple }\end{array}$ & & $\begin{array}{ll}m i: & p a: \\
\text { have } & \text { big knife }\end{array}$ \\
\hline CL2.3 & & $\begin{array}{c}\text { (Ø: man) } \\
\text { 3sg }\end{array}$ & $\begin{array}{l}k o ? \\
\text { then }\end{array}$ & $\begin{array}{lll}\text { ?aw } & \text { pa: } \quad p a j \\
\text { take } & \text { big_knife DIV }\end{array}$ \\
\hline
\end{tabular}

'The people going to the forest, if they have a big knife, bring a big knife.'

\begin{tabular}{|c|c|c|c|}
\hline CL3.1 & $\begin{array}{l}(\varnothing: \text { man }) \\
\downarrow 3 \text { sg }\end{array}$ & & $\begin{array}{l}\text { mi: khwa:n } \\
\text { have axe }\end{array}$ \\
\hline CL3.2 & $\begin{array}{l}(\varnothing: \text { man }) \\
\downarrow 3 s g\end{array}$ & $\begin{array}{l}k o ? \\
\text { then }\end{array}$ & $\begin{array}{lll}\text { Paw } & \text { khwa:n } & \text { paj } \\
\text { Take } & \text { axw } & \text { DIV }\end{array}$ \\
\hline CL3.3 & (Ø: man) & & $\begin{array}{lll}\text { hu: } & \text { mi: } & \text { puan } \\
\text { know have } & \text { gun }\end{array}$ \\
\hline CL3.4 & $\begin{array}{c}\text { (Ø: man) } \\
3 s g\end{array}$ & $\begin{array}{l}k o ? \\
\text { then }\end{array}$ & $\begin{array}{ll}\text { Paw puan } & \text { paj } \\
\text { Take gun } & \text { DIV }\end{array}$ \\
\hline
\end{tabular}

'The one who has an axe, bring an axe. (The one) who has a gun, bring a gun.'

\begin{tabular}{|c|c|c|c|c|}
\hline CL4.1 & $\begin{array}{l}\text { toe? } \\
\text { but }\end{array}$ & 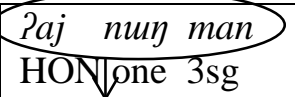 & & $\begin{array}{llll}\text { bo: } & \text { mi: } & \text { hay } & \text { paj } \\
\text { not } & \text { have } & \text { what } & \text { DIV }\end{array}$ \\
\hline CL4.2 & & $\begin{array}{l}\text { (Ø: man) } \\
\downarrow^{3 \text { sg }}\end{array}$ & $\begin{array}{l}\text { ko? } \\
\text { then }\end{array}$ & $\begin{array}{lll}\text { paj } & \text { toe: } & \text { mu: la: la: } \\
\text { go only } & \text { bare hands }\end{array}$ \\
\hline CL4.3 & & $\begin{array}{c}\text { (Ø: man) } \\
\text { 3sg }\end{array}$ & & $\begin{array}{ll}\text { paj po: } & \text { ta? swa } \\
\text { go meet } & \text { tiger }\end{array}$ \\
\hline
\end{tabular}

'But (there was) one man, he brought nothing (to the jungle). (He) went there barehanded. (He) met a tiger.'

There are two referential chains created in this discourse. The first one is a referential chain of the people, while the second one is that of one man. For the first chain, the zero pronoun of the full pronoun man 'he' in CL2.3 and CL3.1-CL3.4 refers to the primary referent in CL2.1 which is mentioned again in CL2.2 without an honorific form. These zero pronouns are used to create a chain of references in developing narrative discourse. The zero anaphor of the full pronoun man mentioned in CL2.3 and in CL3.1-Cl3.4 follows the expression to which it refers (i.e. its referent). The antecedent referent is considered to be unmarked topical theme functioning as subject of the referential chain. This antecedent referent is first introduced in CL2.1. After that, this topic is continued in the subsequent clauses as mentioned before by means of zero pronouns in order to maintain the same participant. The full form of a noun group consisting of an honorific form $? a j$ and a noun kon haw 'people' and of its zero pronouns within the Theme are coreferential, all sharing the same referent. The second referential chain starts from CL4.2 with the zero pronoun man 'he' referring forward to which it refers and then extends to CL4.3 before a new topic is introduced. The zero pronouns in the second referential chain also function as subject of the clause following its antecedent introduced in CL4.1. The antecedent and its zero form are also co-references pointing to the 
same referent ?aj nuп man 'one man, he'. Along the way to the terminus chain of zero pronoun, the zero anaphor of the full pronoun man 'he' is used to help to avoid repetition and to signal an active referent.

\section{Conclusions}

Zero pronouns in Tai dam can occur in both Theme and Rheme positions. In thematic positions, they function as unmarked topical themes and can be the subjects of clauses. In Rheme position, zero pronouns can occur with transitive verb types functioning as objects of clauses. As for the syntactic distribution of zero pronouns, it can be represented as referent + full pronouns + zero pronouns and referent + zero pronouns. Zero pronouns can appear in nominal positions, including bare nouns, noun phrases, and full pronouns as well.

To understand these semantico-syntactic functions, by using SFG to analyze Theme-Rheme structure, it is clear that zero pronouns are consistently realized as unmarked topical themes by giving all chronological linkages, such as temporal and spatial expressions being analyzed under textual themes. Without doing this, if a speaker wishes to change chronological order for example, zero pronouns must be located in the Rheme position, which is not realized as an unmarked topical theme. This particular aspect assists in analyzing full pronouns as well. In terms of discourse function, this finding helps to support the fact that zero pronouns in Tai Dam, which are located in the topical theme, are always realized as unmarked topical themes. By doing this, zero pronouns are primarily used to function as cohesive devices in maintaining a previous discourse referent or reiterate antecedent referents at text discontinuities. They function to highlight a participant through emphasis.

Further research in Tai Dam should focus on discourse functions of zero pronouns as cohesive devices in everyday conversation. Besides zero pronouns, there remain many types of pronouns to be studied for further research on pro-drop phenomena. Moreover, personal pronouns, first person pronouns, and second person pronouns should be studied in narratives and other kinds of discourse.

\section{Acknowledgments}

Financial support from the Thailand Research Fund through the Royal Golden Jubilee Ph.D. Program (Grant No. PHD/0186/2551) to Mr. Itsarate Dolphen and Prof. Somsonge Burusphat is acknowledged.

\section{References}

Aroonmanakun, Wirote Aroonmanakun. 1997. Referent resolution for zero pronouns in Thai. In Abramson, Arthur (ed.) Southeast Asian Linguistic Studies in Honour of Vichin Panupong.

Aroonmanakun, Wirote Aroonmanakun. 1999. Extending focusing for zero pronoun resolution in Thai. $\mathrm{PhD}$ dissertation, Georgetown University.

Aroonmanakun, Wirote Aroonmanakun. 2000. Zero pronoun resolution in Thai: A centering approach. In Burnham, Denis, ed. al. Interdisciplinary Approaches to Language Processing: The International Conference on Human and Machine Processing of Language and Speech. NECTEC: Bangkok, 127147.

Bamroongraks, Cholticha. 1987. Sukhothai Thai as a discourse-oriented language: Evidence from zero noun phrases. PhD dissertation, The University of Wisconsin, Madison.

Burusphat, Somsonge. 1981. A Lao Song folk play called 'In kon’ at Bangkung district. Language and Culture, 1(2), 18-28.

Butt, David, Rhondda Fahey, Susan Feez, and Sue Spinks. 2000. Using Functional Grammar: An Explorer's Guide. Sydney: Robert Burton Printers.

Chomaitong, K. 1974. A contrastive analysis of English and Thai pronouns. MA thesis, University of Illinois.

Compton, Carol J. 1992. Lao pronoun usage as reflected in post-1975 Literature, in Martha Ratliff and Eric Schiller (eds). Paper from the First Annual Meeting of The Southeast Asian Linguistic Society 1991. Temp, AZ: Arizona State University.

Dolphen, Itsarate. 2015. A Comparison of Pronouns in Narratives Discourse in Southeast Asian Languages. PhD dissertation, Mahidol University, Thailand. 
Edwards, Timothy A. 2011. Participant reference in Tai Dam narrative discourse. MA thesis, Payap University, Thailand.

Gürel, Ayşe. 2002. Linguistic characteristics of second language acquisition and first language attrition: overt versus null pronouns. PhD dissertation, McGill University, Montréal, Canada.

Halliday, M. A. K. 1956. Grammatical categories in modern Chinese, Transaction of the Philological Society, 177-224.

Halliday, M. A. K., and Matthiessen, C. M. I. M. 2004. An introduction to functional grammar. Third revised edition of M.A.K. Halliday, An Introduction to Functional Grammar. London: Hodder-Arnold.

Hartmann, John F. 1981. Computations on a Black Tai origin myth. Anthropological Linguistics, 23(5), 183202.

Hartmann, John F. 1992. Diachrony and sociological shifts in Tai pronouns. Southeast Asian Linguistic Society Annual Meeting. Arizona State University, Tempe.

Hasan, Ruqaiya. 1978. Text in the systemic functional model. In W. Dressler (ed.) Current Trends in Text Linguistics, 228-246.

Indrambarya, Kitima. 2010. Zero-pronoun subjects in Thai. In Papers presented on a conference of a PanDialectal Grammar of Thai project. Bangkok : A.S.P. Publishers, 78-102.

Kawahara, D. and S. Kurohashi. 2004. Zero pronoun resolution based on automatically constructed case frames and structural preference of antecedents. In Proceedings of the 1st International Joint Conference on Natural Language Processing, 334-341.

Luis, Alonso-Ovalle and Francesco D'Introno. 2001. Full Pronouns in Spanish: the Zero Pronoun Hypothesis. Hispanic Linguistics at the Turn of the Myllenium, ed. by Héctor Campos et al. Somerville, MA: Cascadilla Press, 189-210.

Maneekhao, K. 1990. Referents for participants in Mien narrative discourse. MA thesis, Chulalongkorn University, Thailand.

Martin, James R. 1992. English text: system and structure. Amsterdam: John Benjamins Co.

Muhlhuasler, Peter and Rom Harre. 1990. Pronouns and people: The linguistic construction of social and personal identity. Blackwell Publishers.

Palakornkul, Angkab. 1985. A socio-linguistic study of pronominal strategy in spoken Bangkok Thai, International Journal of the Sociology of Language, 5, 11-42.

Patpong, Pattama. 2002. Thematic organization of Thai narrative discourse. Papers presented at ASFLA conference: Exploring Systemics at Macquarie University. July 5, 2002.

Roh, J.-E., \& Lee, J.-H. 2006. Generation of Zero Pronouns Based on the Centering Theory and Pairwise Salience of Entities, IEICE Transactions on Information and Systems, E880D(2), 837-846.

Strecker, David S. 1984. Proto-Tai personal pronouns. PhD dissertation, The University of Michigan.

Sukonthaman, Piyanat. 1989. A comparison of Thai second person pronominal acquisition by central Thai and Lahu children (pronominal acquisition). PhD dissertation, University of Illinois.

Thompson, Geoff. 2004. Introducing Functional Grammar ( $2^{\text {nd }}$ ed.). London: Arnold Publication.

Udomwej, S. 1985. Thai Song Dam literature, Khao Yoj district, Phetchaburi province. Petchaburi Rajabhat University, Academic Resources and Information Technology Center.

Zhao, Shu-bin, Hwee Tou Ng 2007. Identification and resolution of Chinese zero pronouns: A machine learning approach. In Proceedings of the 2007 Joint Conference on Empirical Methods in Natural Language Processing and Computational Natural Language Learning (EMNLP-CoNLL), Prague, Czech Republic.

Reviewed: Received 3 August 2016, revised text accepted 7 March 2017, published 20 March 2017

Editors: Editor-In-Chief Dr Mark Alves | Managing Eds. Dr Paul Sidwell, Dr Nathan Hill, Dr Sigrid Lew 